\title{
What is the role of the pharmacist? Physicians' and nurses' perspectives in community and hospital settings of Santiago de Cuba
}

\author{
Niurka María Dupotey Varela ${ }^{1 *}$, Djenane Ramalho de Oliveira ${ }^{2,3}$, Caridad Sedeño Argilagos $^{4}$, Kisvel \\ Oliveros Castro ${ }^{1}$, Elisveidis Mosqueda Pérez ${ }^{1}$, Yelina Hidalgo Clavel ${ }^{1}$, Nelly Sánchez Bisset ${ }^{1}$
}

\author{
${ }^{1}$ Pharmacy Department, Natural Sciences Faculty, Universidad de Oriente, Santiago de Cuba, ${ }^{2}$ Department of Social \\ Pharmacy, College of Pharmacy, Federal University of Minas Gerais, ${ }^{3}$ Medication Therapy Management Program, Fairview \\ Pharmacy Services, Minneapolis, Minnesota, ${ }^{4}$ Pharmacy and Foods Institute. Havana University Cuba
}

\begin{abstract}
This study was carried out to understand the perceptions and expectations of the other health care professionals about pharmacists' role in primary health care centers and hospitals in Santiago de Cuba (Cuba). A cross-sectional descriptive study was conducted, applying a self-administered questionnaire to health care professionals. The sample included 763 professionals $(40.9 \%$ physicians and $59.1 \%$ nurses) from hospitals and primary health care clinics, chosen by random stratified sampling,. The most common activity performed by pharmacists was the distribution of medications or the drug supply management $(51.5 \%)$ and adverse drug reactions reporting (29.4\%), activities performed daily by pharmacists. Pharmaceutical care practice was considered as poor by the professionals, and only $15.6 \%$ of them have collaborated in these programs in the past. For nurses and physicians, interprofessional communication occurs sometimes (56.9\%) and never (25.8\%). Pharmacists' integration into the health team was considered as fair $(50.7 \%)$. A total of $70.1 \%$ perceived the pharmacist as a drug expert and $60.1 \%$ as a professional who provides medication counseling. The main expectations these health care professionals expressed were that pharmacists provide more education about medication (97.4\%) and improve their interprofessional communication techniques in order to communicate more effectively with the other members of the health care team $(96.6 \%)$.
\end{abstract}

Uniterms: Pharmacists/professional functions. Pharmaceutical care. Interprofessional communication.

O presente trabalho analisa o papel do farmacêutico na atenção primária de saúde e em hospitais, na percepção de profissionais da saúde na província de Santiago de Cuba. Um estudo descritivo transversal foi conduzido, através da aplicação de um questionário autoadministrado a uma amostra de 763 profissionais de atenção primária e hospitalar, 40,9\% de médicos e 59,1\% de enfermeiros. As funções farmacêuticas mais reconhecidas pelos profissionais desta amostra foram o fornecimento e distribuição de medicamentos $(51,5 \%)$ e o relato de reações adversas medicamentosas $(29,4 \%)$, funções desenvolvidas diariamente. A prática da atenção farmacêutica é limitada na percepção dos profissionais e apenas 15,6\% têm participado em programas desse tipo. Comunicação interprofissional ocorre às vezes $(56,9 \%) \mathrm{e}$ nunca $(25,8 \%)$, com maiores dificuldades na atenção primária de saúde. A integração do farmacêutico na equipe de saúde foi considerada regular $(50,7 \%)$. Um total de $70,1 \%$ dos profissionais percebeu o farmacêutico como especialista em medicamentos e $64,1 \%$ como o profissional que aconselha sobre o uso de medicamentos. As principais expectativas colocam-se na necessidade de que o farmacêutico ofereça educação sobre o uso de medicamentos $(97,4 \%)$ e reforce as suas técnicas da comunicação na equipe multidisciplinar $(96,6 \%)$.

Unitermos: Farmacêutico/funções profissionais. Atenção farmacêutica. Comunicação interprofissional.

\footnotetext{
*Correspondence: N. D. Varela. Pharmacy Department, Natural Sciences Faculty, Universidad de Oriente, Santiago de Cuba. Cuba, Institutional Address: Patrício Lumumba Avenue, Santiago de Cuba. Cuba, CP 95400. E-mail: dupotey@cnt.uo.edu.cu; niurkadupotey@gmail.com
} 


\section{INTRODUCTION}

Professions exist to serve society. Therefore, the mission of the pharmacy profession must be to address the drug-related needs of society and individual patients. (Hepler, 1985).

Over the past 40 years, the pharmacist's role has been changing from that of compounder and dispenser of medicines to one of "drug therapy manager" (World Health Organization, International Pharmaceutical Federation, 2006). In the 21 st century, the pharmacy profession continues to move toward a patient-centered practice (Ramalho de Oliveira, Shoemaker, 2006). This professional practice model or new approach to patient care is being called pharmaceutical care, medication therapy management or cognitive services, and represents a major transformation in the social responsibility of pharmacists. It is a paradigmatic change that redefines the identity of the pharmacist as a health care provider which has the patient as the focus of practice (Ramalho de Oliveira, 2009).

In the health care field, it is expected and assumed that physicians, pharmacists, nurses and others professionals make clinical decisions anchored in a strong ethical perspective (Martínez, Baena, 2001). Also, there is an increasing interest among health care professionals to optimize patient care by applying a teamwork approach (Florentinus et al., 2006). The World Health Professions Alliance was established in 1999 to facilitate close collaboration between the International Pharmaceutical Federation (FIP), the World Medical Association (WMA), the International Council of Nurses (ICN), and the World Dental Federation (FDI) in support of governments, policy-makers, and the World Health Organization (WHO) with the purpose of delivering higher quality and more cost-effective health care worldwide (www.whpa.org). Through this alliance, over 20 million health care professionals can be reached worldwide, providing a valuable source of knowledge and experience.

The health care team consists of the patient and all the health care professionals who have responsibility for patient care. This team needs to be well defined, and collaboration needs to be actively sought. It is believed that pharmacists have an important role to play in this team. However, they will need to adapt their knowledge, skills and attitudes to this new role, which integrates traditional pharmaceutical science knowledge with clinical aspects of patient care, namely clinical, management and communication skills, ability to actively collaborate with medical teams, and competence to prevent and resolve medicinerelated problems (WHO, IPF, 2006).

It should be highlighted that the practice of pharmaceutical care does not exist and should not exist in isolation from other health care services. It must be provided in collaboration with patients, physicians, nurses, and other health care providers. The pharmaceutical care practitioner develops a partnership with the patient and other providers in order to ensure patients get the most benefit from all their medications (Dupotey, Ramalho de Oliveira, 2009).

The Cuban Health System has a remarkable reputation in the public health services, showing excellent indicators in Latin America, almost comparable with those of developing countries worldwide. However, pharmaceutical care practice has not yet been developed by pharmacists in their daily practice. Despite the fact that this practice model was introduced in Cuban pharmaceutical policies in 2005, through the handbook "Norms and Proceedings' for Community and Hospital Pharmacies" (Cuban Ministry of Public Health, 2005; Cuban Ministry of Public Health, 2006; Medication National Program, 2007), there are some implementation barriers to pharmaceutical care, which must be investigated and overcome so that this practice can be developed and systematically available throughout the entire Cuban health care system.

One of the premises of the philosophy of pharmaceutical care is that the patient should be at the center of the practice and be seen as a teacher who can teach the pharmacist about the meanings of being ill and of using medications. As Ramalho de Oliveira and Shoemaker (2006) wrote: "...Members of the profession must be open to learn with and from the patient and develop a holistic comprehension of patients' understandings, beliefs, attitudes, and behaviors toward health, disease, and medications." We would like to go beyond this assertion to underscore that, besides being open to patients, pharmacists should also tend to the expectations and perceptions of other health care providers because, in order to care holistically and effectively for patients, pharmacists must collaborate with other professionals in the community and hospitals. This can also be considered a piece of the humanistic component and of the psychosocial aspects associated with pharmaceutical care practice. In this regard, in recent years, several studies have explored interprofessional perspectives of pharmacists' role, which have gained an increased prominence in the pharmacy literature.

Some of the most recent studies include the analysis of physicians' perceptions of pharmacists' provision of medication therapy management services to outpatients in Chicago, United States (Padiyara, Rabi, 2006), doctors' and nurses' perceptions of pharmacists' activities in university teaching hospitals in Nigeria (Olubunmi, Oyedepo, Erhun, 2009), and pharmacists' contributions to basic health care from the perspectives of professionals 
of the familial health care teams in Santa Catarina, Brazil (Loch-Neckel, Crepaldi, 2009), etc.

In fact, nowadays, the knowledge of the meanings of pharmacists' work and roles by physicians and nurses acquires a special significance in the exploration of the status of pharmacy practice. These perspectives can assist the profession to better understand pharmacists' situation in the health care system so that it can be enhanced, changed and advanced to better meet our patients' drug-related needs. This study was conducted in response to this social need. Its goal was to reveal pharmacists' roles in the health care system through the eyes of physicians and nurses in community and hospital settings in Santiago de Cuba.

\section{METHODS}

\section{Study characteristics, setting, sample and ethical considerations}

This was a descriptive and cross-sectional study, carried out during the months of February, March, and April of 2007 and 2008. The sample included 763 professionals, 361 from hospitals and 402 from primary health care clinics in Santiago de Cuba City. More specifically, this study included physicians and nurses who work at 12 hospitals in several municipalities (Santiago de Cuba, San Luis, Songo La Maya, Palma Soriano, and Contramaestre) and at some primary health clinics located in the surroundings of the Principal Municipal Pharmacy of Santiago de Cuba, which includes 4 districts. For the hospital settings, the sample size was calculated from a finite population of 5,960 professionals, and for primary health care services the sample size was calculated considering an unknown population size (this information was not accessible to the research team). The samples were chosen by stratified random sampling, with a $95 \%$ of confidence level.

The research project was approved by the Institutional Review Board/Research Committee of the Department of Pharmacy, Faculty of Natural Sciences of The Oriente University, Santiago de Cuba, Cuba. All participants were clarified about the objectives and methods of the study by means of reading and explaining the informed consent form and having it signed. This research did not present risks for its participants; they were assured about confidentiality and received reassurance that the results will be shared with them.

\section{Variables, instruments and procedures to analysis}

The data was collected through a self-administered questionnaire by the professionals. Before its application, this instrument was analyzed by 10 experts and tested for validation with 160 practicing community and hospital professionals, who accepted to collaborate with the project. Therefore, the final questionnaire was formulated based on the comments of experts and professionals, and included five topics:

- Sample characterization: professional or technical qualification; years of experience; and health care settings where they work.

- Activities performed by pharmacists in a health care team, based on doctors' and nurses' experiences. The frequency of execution of the following professional activities was considered: participation in rounds at hospital; suggestions to optimize prescriptions and administration of medications; provision of drug information; detection and reporting of adverse drug reactions; drug supply management; drug education; teaching; and research.

- $\quad$ Physicians' and nurses' participation in pharmaceutical care programs developed by pharmacists, and their collaboration in the prevention and solution of negative results associated with drug therapy $(A$ Third Spanish Consensus of Pharmaceutical Care was used as reference). (Granada's Research Group, 2007)

- Interprofessional relationship, communication and barriers perceived. The interprofessional relationship was categorized into four categories: excellent, good, fair, and bad. The frequency of communication between these professionals was also obtained. In the case of unsatisfactory responses, the main barriers were identified.

- $\quad$ Perceptions and expectations of pharmacists' role as a health care professional, including the responsibilities on patients' medication therapy and the interaction with the health team.

Descriptive statistics was used to characterize the professionals' samples. All data were analyzed establishing a comparison between health care settings and the professionals' qualifications, through a non-parametric $\chi^{2}$ (chi square), method of contingency tables, with a level of significance $\alpha=0.05$.

\section{RESULTS AND DISCUSSION}

The questionnaire was completed by 763 health care professionals, being $40.9 \%$ physicians and $51.9 \%$ nurses. A total of $47.3 \%$ of the professionals worked at hospitals and $52.7 \%$ at primary health care services. The mean of years of professional experience was 12.6 years. From 
physicians' and nurses' perspectives, the most common activities carried out by pharmacists were drug supply management (70.4\%) and detection and reporting of adverse drug reactions $(51.1 \%)$. Table I shows the frequencies of professionals' perceptions of the various activities performed by pharmacists in different health care settings.

In general, there is a low perception about the performance of clinical functions of pharmacists, as these activities appear in the lowest frequencies of physicians' and nurses' perspectives. Significant differences were found in health care settings, and pharmacists' clinical activities in community pharmacists and other primary care settings had the lowest frequencies. The pharmacist's participation in hospital rounds does not occur from the perspective of $83.9 \%$ of professionals from this setting.

Education on drug use, health promotion, disease prevention and lifestyle modification are activities usually performed at the community level and that have a public health focus. In this case, as shown, these functions are performed monthly, generally in the primary care settings (43.8\%).

In hospitals, a daily review of patients' prescriptions by a pharmacist is necessary. It is well known that most of the drug-related morbidity and mortality in this setting is predictable and can be avoided, which would reduce the duration of hospitalization and, consequently, the overall cost of health care, while improving the quality of care (Traynor, 2009; Abdel-Qader, Harper, Cantrill, Tully, 2010).

However, this daily expected pharmacist intervention is not observed by the majority of the participants in this study. A study that examined medical practitioner's experiences with the role of hospital-based pharmacists in Sudan shows similar results. One half of respondents never or rarely had interactions with pharmacists with regard to their patients' medications, $36.9 \%$ and $13.1 \%$ had this type of contact once per week or once a day or more, respectively. (Awad, Matow, Capps, 2007).

In this study, only $15.6 \%$ of professionals had been contacted to participate in pharmaceutical care programs, generally by community pharmacists. Only 12 professionals participated in pharmaceutical care programs in hospitals. These differences were significant. Regarding professional qualification, only $13.1 \%$ of physicians and $8.4 \%$ of nurses recognized to participate in these programs. Collaboration with pharmacists in preventing and resolving negative outcomes associated with medication was low $(17.7 \%)$, and the most common problems were: untreated health problem $(82.2 \%)$, quantitative ineffectiveness $(80.7 \%)$, and non-quantitative ineffectiveness (78.5\%).

Pharmacists collaborate in the education of pharmacy students in $27.6 \%$, and conduct drug research with

TABLE I - Participants' perceptions of activities carried out by pharmacists in health care teams in different settings

\begin{tabular}{|c|c|c|c|c|c|c|c|c|c|}
\hline \multirow[t]{3}{*}{ Pharmacists' functions } & \multicolumn{9}{|c|}{$\begin{array}{c}\text { Primary health care }(\mathrm{PHC}) \mathrm{n}=402 / \text { Hospital }(\mathrm{H}) \mathrm{n}=361 / \text { Total } 763 \\
\text { Number of professionals - } \mathrm{n} \\
\text { (Percentage) }(\%)\end{array}$} \\
\hline & \multicolumn{2}{|c|}{ Daily } & \multicolumn{2}{|c|}{ Weekly } & \multicolumn{2}{|c|}{ Monthly } & \multicolumn{2}{|c|}{ Not performed } & \multirow{2}{*}{$p$ value } \\
\hline & PHC & $\mathrm{H}$ & PHC & $\mathrm{H}$ & PHC & $\mathrm{H}$ & PHC & $\mathrm{H}$ & \\
\hline $\begin{array}{l}\text { Patient care rounds at } \\
\text { hospital }\end{array}$ & - & $14(3.9)$ & - & $19(5.3)$ & - & $25(6.9)$ & - & $303(83.9)$ & - \\
\hline $\begin{array}{l}\text { Suggestions to optimize } \\
\text { drug prescriptions and } \\
\text { administration }\end{array}$ & $16(4.0)$ & $84(24.1)$ & $99(24.6)$ & $52(14.4)$ & $167(41.5)$ & $70(19.4)$ & $120(29.8)$ & $152(42.1)$ & $p=0.000$ \\
\hline $\begin{array}{l}\text { Detection and reporting } \\
\text { of drug adverse reactions }\end{array}$ & $32(8.0)$ & $192(53.2)$ & $135(33.6)$ & $31(8.6)$ & $134(33,3)$ & $50(13.9)$ & 99 (24.6) & $88(24.4)$ & $p=0.000$ \\
\hline $\begin{array}{l}\text { Drug supply } \\
\text { management and } \\
\text { dispensation }\end{array}$ & $88(21.9)$ & $\mathbf{3 0 5}(84.5)$ & $113(28.1)$ & $12(3.3)$ & $128(31.8)$ & $11(3.0)$ & $73(18.1)$ & $33(9.14)$ & $p=0.000$ \\
\hline $\begin{array}{l}\text { Drug information to } \\
\text { health care professionals }\end{array}$ & $27(6.7)$ & $110(30.5)$ & $129(32.1)$ & $68(18.8)$ & $149(37.1)$ & $78(21.6)$ & $97(24.1)$ & $105(29.1)$ & $p=0.000$ \\
\hline $\begin{array}{l}\text { Drug education and } \\
\text { health promotion } \\
\text { activities }\end{array}$ & $20(5.0)$ & $58(16.1)$ & $112(27.9)$ & $73(20.2)$ & $176(43.8)$ & $75(20.8)$ & $94(23.4)$ & $155(42.9)$ & $p=0.000$ \\
\hline
\end{tabular}




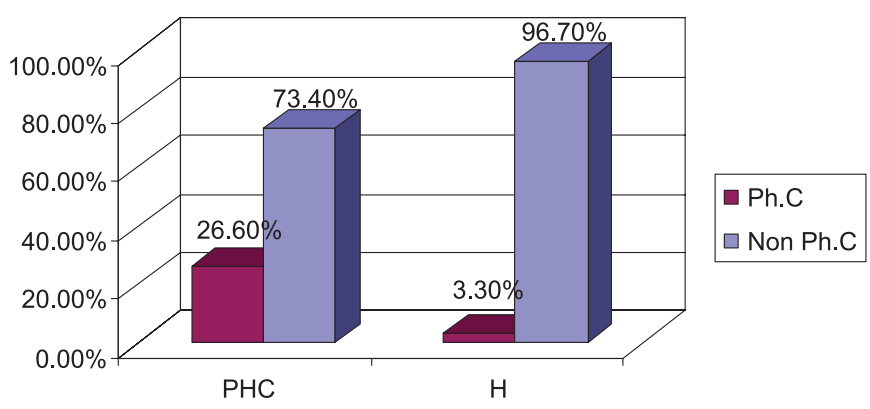

Legends: Ph. C: Participation in pharmaceutical care programs; Non $\mathrm{Ph}$. C: Non participation in pharmaceutical care programs; PHC: Primary health care H: Hospital

FIGURE 1 - Professionals' participation in pharmaceutical care programs. $\mathrm{p}=0.001$

a health care team in $33 \%$; in this last case, there was not a statistical difference between the different health care settings.

Another study, conducted by Penaforte, Forste, and Simões in Ribeirão Preto, Brazil, assessed the practices of pharmacists in a hospital setting. A structured instrument was applied and the following five areas were analyzed: sector management, hospital compounding, committee activities, information and pharmacotherapeutic followup, as well as teaching and research activities. They found that some essential services such as drug information service and pharmacotherapeutic follow-up were absent (Penaforte, Forste, Simões, 2007). These results illustrate how pharmacists' practice is still focused on drugs and not on patients. Precisely, these clinical functions, which have the potential to encourage the social recognition of pharmacists, are rarely carried out, both from physicians' and nurses' perspectives.

Similar findings were found in a previous study performed to characterize the professional practice of pharmacists in Santiago de Cuba, from their own points of view. In this research, the most frequent activities observed were administrative functions and dispensing. (Martínez, Dupotey, Brea, 1999). It is troublesome that this is still the reality today. Pharmaceutical care practice is scarce and not systematic in Cuba. The analysis of $\mathrm{Cu}-$ ban pharmacists' contexts of practice could explain this phenomenon. There are no legislation or pharmaceutical policies regulating the provision of pharmaceutical care services. Pharmacists' activities are regulated by the National Direction of Pharmacy, through the "Norms and Proceedings for Community and Hospital Pharmacies". This document presents gaps and misconceptions about the definition of pharmaceutical care, its implementation and evaluation, according to the most recent and basic understandings of this practice model. (Cipolle, Strand, Morley, 2004; Comité de Consenso de Granada, 2007; Ramalho de Oliveira, 2010). On the other hand, there is a document that regulates the legal functions of pharmacists in Cuba, called "Qualifier of Charges for Pharmacists" (Cuban Ministry of Public Health, 2005), which states a list of many different functions that should be carried out by pharmacists and are completely disconnected from the reality of a clinical practice model such as pharmaceutical care. Furthermore, these activities have no connection to a social need and to the requirements described in the "Norms and Proceedings for Community and Hospital Pharmacies."

On the other hand, pharmaceutical care in Cuba is usually developed at experimental level, not at practice level. There are structural aspects under analysis that limit the development and delivery of services such as pharmacotherapy follow-up. For instance, many pharmacies do not have a private room for patients' consultations; moreover, they have a small number of pharmacists dedicated to clinical functions and a large number of pharmacists performing several functions at the same time. The $\mathrm{Mu}$ nicipal Pharmacy, which is the main community pharmacy of the territory and controls the activities that take place in all the other pharmacies, is the only pharmacy that has a clinical pharmacist in its staff as a legal determination. In the other community and hospital pharmacies, this function is expected from the pharmacist in response to a specific situation or a requirement of the boss.

The pharmacists' integration with the health care team was considered by physicians and nurses as fair $(50.7 \%)$, good (32.1\%), bad (15.5\%), and excellent (only $2.1 \%)$. Significant differences in the health care settings were found $(p=0.018)$. In a hospital environment, pharmacists are more integrated with the health care team. There was a large number of pharmacists who perform clinical functions daily in hospitals.

In the hospital setting, pharmacists have an excellent opportunity to interact with patients, to access patients' clinical records (including medication therapies), and to have more interaction with physicians and nurses, which permit the establishment of common strategies to optimize patients' medication therapies. Hospital pharmacy has led the way to expand the role of pharmacy technicians so that pharmacists can have a bigger role in direct patient care (Royal Pharmaceutical Society of Great Britain, 2006).

In the hospital setting, pharmacists may participate in patient care rounds with physicians and other health care providers, counsel patients, and offer information/ education to other health care providers. Pharmacists participate in key committees at these institutions, includ- 
ing the Pharmacy and Therapeutics Committee, antibiotic monitoring committees, and medication safety committees. Pharmacists also practice in many other settings such as ambulatory care clinics, managed care, and long-term care, and participate in a number of pharmaceutical services (Zeind, Mc Closkey, 2006).

Table II shows the barriers identified by participants with regard to establishing professional relationships.

The most important barriers perceived by professionals in establishing a relationship with pharmacists were: "I don't know who the pharmacist is" (37.6\%); "The pharmacist has not contacted me" (36.0\%); lack of time of physicians and nurses (33.4\%); and lack of time of the pharmacist (33.4\%). These findings suggest a low level of communication between health providers and pharmacists, which is corroborated by the frequencies perceived by the professionals (always $=17.3 \%$, sometimes $=56.9 \%$ and never $=25.8 \%$ ).

Statistical differences were found in health settings and professional qualification. Specifically, in primary health care clinics, the professionals considered the lack of pharmacists' time as the main barrier to the relationship (65.4\%). In the hospital setting, professionals did not know who the pharmacist is $(48.8 \%)$. Regarding professional qualification, $34.6 \%$ of physicians believe that lack of pharmacist's time is the main barrier and $41.7 \%$ of nurses do not know who the pharmacist is.

Ethical issues in interprofessional communication appear in $15.7 \%$ of responses, being $27.0 \%$ in primary care and $13.3 \%$ in the hospital setting. Many barriers have been mentioned by different authors. Communication troubles and lack of time of pharmacists and of other health providers have been found in studies that explored facilitators (Gastelurrutia et al., 2009) and barriers to pharmacotherapy follow-up (Hidalgo et al., 2005), and the implementation of pharmaceutical care services (Uema et al., 2008). A research study performed by the Pharmaceutical Care Network Europe compiled and structured into domains a list of 25 barriers, identified by structured interviews with pharmacists from 11 European countries. The barriers were compiled in five domains: resources, attitudes and opinions, education, skills, and environment. According to the interviewees, the lack of time, the attitude/opinion of other professionals and the lack of communication skills were the major barriers perceived in all participant countries (Foop, 2000).

Insufficient communication between pharmacists and physicians occurs for several reasons. One barrier that has been cited is pharmacists' expressed lack of confidence in their ability to persuade physicians to accept their recommendations. Another possible cause is ineffective or needless communication initiated by pharmacists, which makes physicians less willing to listen to pharmacists during future interactions (Ranelli, Biss, 2000). With communication so limited, physicians are unable to benefit from a pharmacist's suggestion about drug therapy.

Respondents' perceptions of pharmacists are shown in Table III. The most common perceptions were: the pharmacist is a drug expert (70.1\%), the pharmacist counsels patients about their drugs (64.1\%), and the pharmacist exclusively supplies, controls and dispenses drugs (61.3\%).

Similarly, significant differences in health care settings and physicians' and nurses' perceptions were found. Fifty percent of professionals of primary health care consider the pharmacist as someone who counsels about the use of drugs, and $96.7 \%$ of hospital health providers consider the pharmacist as someone who exclusively delivers, controls and dispenses drugs. The professionals

TABLE II - Barriers to interprofessional relationship perceived by participants

\begin{tabular}{lcccccc}
\hline \multirow{2}{*}{ Barriers } & \multicolumn{3}{c}{ Primary health care } & \multicolumn{3}{c}{ Hospital } \\
\cline { 2 - 6 } & Phys. (\%) & Nurs. (\%) & Total (\%) & Phys. (\%) & Nurs. (\%) & Total (\%) \\
\hline Lack of pharmacist's time & $91(52.3)$ & $83(47.7)$ & $\mathbf{1 7 4 ( 6 5 . 2 )}$ & $17(21.0)$ & $64(79.0)$ & $81(22.4)$ \\
I don't know who the pharmacist is & $50(45.1)$ & $61(54.9)$ & $111(41.6)$ & $49(27.8)$ & $127(72.2)$ & $\mathbf{1 7 6 ( 4 8 . 8 )}$ \\
Lack of time of physician or nurse & $\mathbf{7 7 ( 5 5 . 0 )}$ & $63(45.0)$ & $\mathbf{1 4 0 ( 5 2 . 4 )}$ & $21(17.4)$ & $100(82.6)$ & $121(33.5)$ \\
Underutilization of pharmacist as a & $44(59.4)$ & $40(52.3)$ & $\mathbf{7 4 ( 2 7 . 7 )}$ & $8(47.1)$ & $9(52.9)$ & $17(4.7)$ \\
medication expert & & & & & & \\
I don't trust the pharmacist & $33(50.0)$ & $33(50.0)$ & $\mathbf{6 6 ( 2 4 . 7 )}$ & $1(14.3)$ & $6(85.7)$ & $7(1.9)$ \\
The pharmacist has not contacted me & $60(45.1)$ & $73(54.9)$ & $\mathbf{1 3 3 ( 4 9 . 8 )}$ & $42(29.6)$ & $100(70.4)$ & $142(39.3)$ \\
Ethical troubles in interprofessional & $33(45.8)$ & $39(54.2)$ & $\mathbf{7 2 ( 2 7 . 0 )}$ & $8(16.7)$ & $40(83.3)$ & $48(13.3)$ \\
communication & & & & & & \\
\hline
\end{tabular}

Phys. Physicians; Nurs. Nurses; $p_{a}=0.000$ - Probability calculated according to health care settings; $p_{b}=0.033$ - Probability calculated according to professional qualification 
TABLE III - Professional's perceptions of pharmacists's role

\begin{tabular}{|c|c|c|c|c|c|c|}
\hline \multirow{2}{*}{$\begin{array}{l}\text { Professionals' perceptions of } \\
\text { pharmacists }\end{array}$} & \multicolumn{3}{|c|}{ Primary health Care } & \multicolumn{3}{|c|}{ Hospital } \\
\hline & Phys. (\%) & Nurs. (\%) & Total $(\%)$ & Phys. (\%) & Nurs. (\%) & Total $(\%)$ \\
\hline Professional expert on drugs & $92(47.2)$ & $103(52.8)$ & $195(48.5)$ & $94(27.7)$ & $246(72.3)$ & $340(94.2)$ \\
\hline Counsels on the use of drugs & $105(52.2)$ & $96(47.8)$ & $201(50.0)$ & $81(28.1)$ & 207 (71.9) & $288(79.8)$ \\
\hline $\begin{array}{l}\text { Exclusively supplies, controls and } \\
\text { dispenses drugs }\end{array}$ & $50(42.0)$ & $69(58.0)$ & $119(29.6)$ & $93(26.7)$ & $256(73.4)$ & $349(96.7)$ \\
\hline $\begin{array}{l}\text { Responsible for the drug problems } \\
\text { of the patients }\end{array}$ & $11(55.0)$ & $9(45.0)$ & $20(5.6)$ & $44(28.2)$ & $112(71.8)$ & $156(43.2)$ \\
\hline The physician' and nurse' partner & $78(83.0)$ & $16(17.0)$ & $94(23.4)$ & $49(33.5)$ & $117(66.5)$ & $166(46.0)$ \\
\hline
\end{tabular}
in the decision-making process on medications

$\mathrm{p}_{\mathrm{a}}=0.000$ - Probability calculated according to health care settings; $\mathrm{p}_{\mathrm{b}}=0.000$ - Probability calculated according to professional qualification

recognized the expertise of pharmacists in pharmacotherapy according to their competence and knowledge area. Moreover, the functions most often perceived by professionals are associated with their perceptions.

Particularly, physicians perceive pharmacists as drug experts and as counselors in equal proportion (59.6\%). The nurses perceive the pharmacist as a drug expert (77.3\%) and as someone who exclusively supplies drugs (72.1\%). In fact, the relationship between pharmacists and nurses in drug supply functions can be considered a response to these limited perceptions.

Ranelli and Biss (2000) studied physicians' perceptions of communication with and responsibilities of pharmacists. Structured interviews and a survey mailed to a convenience sample of physicians were conducted. Respondents were most comfortable with pharmacists' responsibilities of identifying prescription errors (88.0\%), providing patient education (65.1\%), suggesting nonprescription medications (63.4\%), and suggesting prescription medications to physicians $(52.0 \%)$. For $79.2 \%$ of respondents, an office nurse had the most contact with pharmacists.

Harriman et al. (2010) identified physicians' perceptions of community pharmacists' provision of medication therapy management through a qualitative analysis. The need for a trusting relationship between a patient's primary care physician and the pharmacist providing medication therapy management was identified.

Similarly, Olubunmi, Oyedepo and Erhun (2009) examined the attitudes of 90 doctors and 160 nurses towards pharmacists' activities in three university teaching hospitals in Southwestern Nigeria. The activities were grouped into four domains: the pharmacist's influence on prescribing and medicine use, dispensing of prescription medications, participation in health promotion, and drug supply management. Dispensing functions ranked highest, while medicine supply activities were rated lowest in importance. Both groups rated pharmacists' performance lowest in dispensing functions. However, as a result of inadequacies detected in clinical skills, according to participants, the pharmacist's impact was minimal in the areas of therapeutic drug monitoring, promotion of public health, and patient counseling.

The expectations are presented in Table IV. The physicians and nurses have high expectations of pharmacists as knowledgeable drug therapy experts and expect them to apply this knowledge in prescription and drug use monitoring.

To offer education and counseling about drugs to patients and other health providers $(97.4 \%)$, and to improve the skills for a better interprofessional communication $(96.6 \%)$ were the most frequent expectations of physicians and nurses, which correspond to their perceived needs.

In addition, they expect pharmacists to optimize the prescriptions through recommendations $(96.1 \%)$ and to improve clinical training in drug-related problems $(95.8 \%)$. Similar research findings indicated that physicians want pharmacists to communicate with them. In one study, physicians recommended that pharmacists notify them first, even before the patient, when possible problems with drug dose, allergy, or interactions arise. In another study of physicians' opinions, physicians believed that pharmacists were competent and knowledgeable and thus should be doing more than just dispensing medications. (Ranelli, Biss, 2000).

Statistical differences in both health care settings were not found, but for physicians and nurses the results were not the same. Both professional groups share the 
TABLE IV - Professionals' expectations of pharmacists' role

\begin{tabular}{lcccccc}
\hline $\begin{array}{l}\text { Professionals' expectations of } \\
\text { pharmacists }\end{array}$ & \multicolumn{3}{c}{ Primary health care } & \multicolumn{3}{c}{ Hospital } \\
\cline { 2 - 6 } & Phys. (\%) & Nurs. (\%) & Total (\%) & Phys. (\%) & Nurs. (\%) & Total (\%) \\
\hline $\begin{array}{l}\text { To improve pharmacists' clinical } \\
\text { training in drug-related problems }\end{array}$ & $205(52.8)$ & $183(47.2)$ & $\mathbf{3 8 8}(96.5)$ & $94(27.4)$ & $249(72.6)$ & $\mathbf{3 4 3}(95.0)$ \\
$\begin{array}{l}\text { To optimize the prescriptions through } \\
\text { recommendations }\end{array}$ & $207(53.6)$ & $179(46.4)$ & $\mathbf{3 8 6}(96.1)$ & $95(27.4)$ & $252(72.6)$ & $\mathbf{3 4 7}(96.1)$ \\
$\begin{array}{l}\text { To assume responsibility for } \\
\text { pharmacotherapy outcomes }\end{array}$ & $166(50.9)$ & $160(49.1)$ & $326(81.1)$ & $83(25.6)$ & $242(74.4)$ & $325(90.0)$ \\
$\begin{array}{l}\text { To collaborate in solving drug-related } \\
\text { problems }\end{array}$ & $185(55.2)$ & $150(44.8)$ & $335(83.3)$ & $85(26.2)$ & $240(73.8)$ & $325(90.0)$ \\
$\begin{array}{l}\text { To offer education and counseling } \\
\text { about drugs }\end{array}$ & $210(53.3)$ & $184(46.7)$ & $\mathbf{3 9 4}(98.0)$ & $95(27.2)$ & $254(72.8)$ & $\mathbf{3 4 9}(97.0)$ \\
$\begin{array}{l}\text { To improve the skills for } \\
\text { interprofessional communication }\end{array}$ & $201(52.3)$ & $183(47.7)$ & $\mathbf{3 8 4}(95.5)$ & $96(27.2)$ & $257(72.8)$ & $\mathbf{3 5 3}(97.8)$ \\
\hline
\end{tabular}

$\mathrm{p}_{\mathrm{a}}=1.000$ Probability calculated according to health care settings; $\mathrm{p}_{\mathrm{b}}=0.000$ Probability calculated according to professional qualification

most common expectations about pharmacists, even though the need for pharmacists to improve their clinical training in drug-related problems is much more frequently expected by physicians $(95.8 \%)$ than nurses $(61.4 \%)$.

In contrast, nurses $(89.1 \%)$ believe more than physicians $(79.8 \%)$ that pharmacists should assume responsibility for pharmacotherapy outcomes. These findings for each group of health providers show how they perceive their relationship with pharmacists, but in general they suggest that physicians and nurses want to interact with competent pharmacists, and with pharmacists engaged in and responsible for patient care and pharmacotherapy outcomes.

The perceptions and expectations identified in this study illuminate the perceived status of the pharmacist in health care settings in Santiago de Cuba, from the perspectives of other health care providers. A wide range of perceptions, understandings and expectations of pharmacists were uncovered in this study so that now we might reflect upon and design strategies to advance pharmacists' role in the health care system. Issues associated with professional functions and responsibilities, pharmaceutical care practice, professional attitudes and competence, interprofessional communication, ethics, pharmacy education, and commitment were raised, and those issues are intimately connected with the social role claimed by the professional of pharmacy today.

It would be even more illustrative to make a holistic analysis of these relationships through the development of a qualitative research design that explores the providers' perceptions by means of open and in-depth interviews focused on the meanings of pharmacists' work for other health care professionals. (Dupotey, Ramalho de Oliveira, 2009).

Pharmacists must demonstrate how important they are for patients in terms of improving their clinical outcomes and quality of life. We believe that this is the only way pharmacists will be able to gain the confidence of physicians, nurses, and the health system in general. It is passed the time for pharmacists to take the challenge that society has presented to them, and organize their time to undertake clinical and cognitive functions, which means working directly with patients and other providers, deliver the best possible care, and document and evaluate the care provided. This is the only way to obtain social recognition and the identity of a health care provider.

\section{CONCLUSIONS}

From physicians and nurses' perspectives, the main activities performed by pharmacists are related with drug supply management and adverse reactions' reporting. Other clinical functions are perceived in low frequency, generally in community pharmacies. Pharmaceutical care is rarely provided, and it is even less frequent in hospitals. Limitations in interprofessional communication and in pharmacists' integration with the health care team have been demonstrated. Although health care providers recognize the pharmacist as a drug expert and as someone who provide counseling on drugs, their expectations are still associated with drug education and the use of more effective communication techniques. The perception of 
pharmacists' roles uncovered in this study is a reflection of current changes in the health care systems that are leading to a greater involvement of the pharmacist in direct patient care. New strategies should be implemented in the health care environment of Santiago de Cuba, and we believe that the acceptance of pharmaceutical care as the new mandate for pharmacists is the right direction.

\section{ACKNOWLEDGEMENTS}

Our research team would like to thank all health care professionals who accepted to collaborate with us and all managers of the hospitals and the primary care centers where the investigation was conducted.

\section{REFERENCES}

ABDEL-QADER, D.; HARPER, L.; CANTRILL, J.; TULLY, M. Pharmacists' interventions in prescribing errors at hospital discharge: an observational study in the context of an electronic prescribing system in a UK Teaching Hospital. Drug Safety., v.33, n.11, p.1027-1044, 2010.

AWAD, A.; MATOWE, L.; CAPPS, P. Medical doctors' perceptions and expectations of the role of hospital pharmacists in Sudan. Pharm. World Sci., v.29, n.5, p.557564, 2007.

CIPOLLE, R.; STRAND, L.; MORLEY, P. Pharmaceutical care practice: the clinician's guide. New York: McGraw Hill, 2004. p.30-57.

COMITÉ DE CONSENSO DE GRANADA. Tercero Consenso de Granada, sobre Problemas Relacionados con Medicamentos (PRM) y Resultados Negativos de la Medicación (RNM). Ars Pharm., v.48, n.1, p. 5-17, 2007.

CUBA. Ministerio de Salud Pública. Manual de Normas y Procedimientos para Farmacia Comunitaria. Ciudad de la Habana: Editorial Ciencias Médicas, 2005. p.12-17.

CUBA. Ministerio de Salud Pública. Manual de Organización para los Servicios Farmacéuticos Hospitalarios. Ciudad de la Habana: Editorial Ciencias Médicas, 2006. p.15-20.

CUBA. Ministerio de Salud Pública. Programa Nacional de los Medicamentos. 2007. p. 1-38. Available at: http://www. sld.cu/galerias/pdf/servicios/medicamentos/programa nacional_de_medicamentos_2007.pdf. Accessed on: 23 Feb. 2011.
DUPOTEY, N.M.; RAMALHO DE OLIVEIRA, D. A qualitative glimpse at pharmaceutical care practice. Pharm. World Sci., v.31, n.6, p. 609-611, 2009.

FLORENTINUS, S.; HULTEN, R.; KRAMER, M.; DIJK, L.; HEERDINK, E.; LEUFKENS, H.; GROENEWEGEN, P. Which pharmacists contribute to high-level pharmacotherapy audit meetings with general practitioners? Ann. Pharmacother., v.40, n.9, p.1640-6, 2006.

FOOP, J.W. Atención Farmacéutica en Farmacia Comunitaria en Europa, retos y barreras. Pharm. Care Esp., v.2, n.1, p.42-56, 2000.

GASTELURRUTIA, M.; BENRIMOJ, S.; CASTRILLON, C.; DE AMEZUA, M.; FERNANDEZ- LLIMOS, F.; FAUS, M. Facilitators for practice change in Spanish community pharmacy. Pharm.World Sci., v.31, n.1, p.32-39. 2009.

HARRIMAN, S.; SNYDER, M.; GARCIA, G.; PRINGLE, J.; SMITH, R.; SOMMA, M. Physician perceptions of pharmacist-provided medication therapy management: qualitative analysis. J. Am. Pharm. Assoc., v.50, n.1, p.6771, 2010.

HEPLER, C. Pharmacy as a clinical profession. Am. J. Hosp. Pharm., v.42, n.6, p.1298-1306, 1985.

HIDALGO, J.; CÁMARA, D.; BAENA, M.I.; FAJARDO, P.C.; MARTÍNEZ, F. Barreras para la implantación del seguimiento farmacoterapéutico en las farmacias comunitarias de Granada (España). Seguim. Farmacoter. v.3, n.3, p.144-149, 2005.

HOEK, A.J.M. Declaraciones de apoyo: Federación Farmacéutica Internacional. Preparación de los profesionales de la atención de salud para el siglo XXI. El reto de las enfermedades crónicas. Available at: $<$ http:// www.infosalud.com.mx/Publicaciones/WHO53.htm>. Accessed on: 21 May 2007.

HOSPITAL pharmacy in the 21st century. Available at: http:// www.rpsgb.org.uk/pdfs/hosppharm21 cbrief.pdf. Accessed on: 31 May 2008.

LOCH-NECKEL, G.; CREPALDI, M.A. Pharmacist contributions for basic care from the perspective of professionals of familial health care teams. Braz. J. Pharm. Sci., v.45, n.2, p.263-272, 2009. 
MARTÍNEZ, A.; DUPOTEY, N.; BREA, G. Actitudes y competencias en el desempeño de funciones profesionales: un acercamiento a su evaluación. Rev. Aten. Farm., v.1, n.3, p.297-301, 1999.

MARTÍNEZ, J.; BAENA, M. I. La Atención Farmacéutica como método para mejorar la salud de los pacientes y la coordinación entre los profesionales médicos y farmacéuticos (Contestación a Enrique Costas Lombardía). Pharm. Care Esp., v.3, n.2, p.135-139, 2001.

OLUBUNMI, M.; OYEDEPO, T.; ERHUN, W. Doctors' and nurses' perceptions of pharmacists' activities in university teaching hospitals in Nigeria. J. Med. Use Developing Countries, v.1, n.3, p.24-36, 2009.

PADIYARA, R.; RABI, S. Physician perceptions of pharmacist provision of outpatient medication therapy management services. J. Am. Pharm. Assoc., v.46, n.6, p.660-663, 2006.

PENAFORTE, T.R.; FORSTE, A.C.; SIMÕES, M.J. Evaluation of the performance of pharmacists in terms of providing health assistance at a university hospital. Clinics, v.62, n.5, p.567-572, 2007.

RAMALHO DE OLIVEIRA, D. Atenção Farmacêutica como construção da realidade. Rev. Racine, v.109, p.94-102, 2009. Available at: < http://www.racine.com.br/portal-racine/ atencao-farmaceutica/conceito/atencao-farmaceuticacomo-construcao-da-realidade>. Accessed on: $1^{\text {st }}$ Mar. 2011.

RAMALHO DE OLIVEIRA, D.; SHOEMAKER, S.J. Achieving patient centeredness in pharmacy practice: openness and the pharmacist's natural attitude. J. Am. Pharm. Assoc., v.46, n.1, p.56-64, 2006.
RAMALHO DE OLIVEIRA, D. The reality of pharmaceutical care practice: patients', pharmacists' and students' perspectives. Koln: Lambert Academic Publishing, 2010. p.382.

RANELLI, P.L.; BISS, J. Physicians' perceptions of communication with and responsibilities of pharmacists. Am. Pharm. Assoc., v.40, n.5, p.625-630, 2000.

ROYAL PHARMACEUTICAL SOCIETY OF GREAT BRITAIN. Pharmacy Briefing. TRYNOR, K. Pharmacist's Follow-Up Helps Cut Hospital Readmissions, ER Use. Health System Pharmacy News. 2009. Available at: <http:// www.ashp.org/import/news/HealthSystemPharmacyNews/ newsarticle.aspx?id=3016> Accessed on: 6 Feb. 2010.

UEMA, S.; VEGA, E.; ARMANDO, P.; FONTANA, D. Barriers to pharmaceutical care in Argentina. Pharm. World Sci., v.30, n.3, p.211-215, 2008.

WORLD HEALTH ORGANIZATION. International Pharmaceutical Federation. Developing pharmacy practice. A focus on patient care. Handbook. Switzerland, Netherlands, 2006. Available at: <http://www.fip.org/ files/fip/publications/DevelopingPharmacyPractice/ DevelopingPharmacyPracticeEN.pdf $>$. Accessed on: 19 Mar 2010.

ZEIND, C.; MCCCLOSKEY, W. Pharmacists' role in the Health Care System. Harvard Health Pol. Rev., v.7, n.1, p.147-154, 2006.

Received for publication on $17^{\text {th }}$ February 2011 Accepted for publication on $12^{\text {th }}$ August 2011 